\title{
A Story to Make You Sad: On Alexis Shotwell's Knowing Otherwise: Race, Gender, and Implicit Understanding
}

\author{
Bettina Bergo
}

In 1892, when the Jewish sociologist Max Nordau published his work Entartung, a study on "the dusk of the nations" that passed through "the psychology of ego-mania," "Parnassians and Diabolists," "decadence and esthetes," he was seeking "to create better conditions for the human organism" by teaching it a different approach to pleasure within the framework of evolution (xvii). In 1897, the physician and student of criminality and anti-Semitism, Cesare Lombroso, published his chef-d'oeuvre Genio e degenerazione. At the same time, in 1896, Magnus Hirschfeld published his Sappho und Sokrates about masculinity and femininity. ${ }^{1}$ He would found the Archiv fur Sexualforschung, which lasted thirty years, until the Nazis destroyed it. The book burnings captured on cellulose were, as we know, the destruction of Hirschfeld's vast library. In 1903, Hirschfeld published the definitive investigation into male homosexuality, Der uranische Mensch (The Uranian Person). In the same year, Otto Weininger's Sex and Character appeared, arguing for a thesis largely received from Hirschfeld, arguing on the basis of the embryology and zoology of the time that sexuation could not be limited to the genitals. Rather, sexuation occurred at the cellular level, in some material that remained mysterious to us - related to the observed coloured bodies within the nucleus. As a result of this, every cell was a blending not of two bonded strands of DNA, but of two physico-chemical elements of sexuation. This meant that every living organism was a republic; the republic was not composed 
of two sexes, but of a spectrum of sexuation. What one became socially, as far as identity was concerned, was a matter of socialization and the medical gaze, cast initially upon the genitals.

Sexuality - its meaning, its origin, its relation to genetic degeneration and criminality, indeed its fundamental relationship to the most vilified minority in Europe at that time, Jewswas the decisive question of the belle époque. It was also the most frightening, and elicited the most violent responses. Weininger's book was a plea for four things: 1) the intrinsic intersexuation of every living being; 2) further research into the dynamics of sexual attraction and orientation based on the calculation of $\mathrm{M}$ or $\mathrm{W}$ factors in a body (Mannlich and Weiblich, male or female); 3) for understanding Jews as a group of people possessed of a larger quantity of femininity in their genes and geniuses as select individuals possessed of greater quantities of masculinity; 4) and finally, a plea to German-speaking intellectuals to espouse an ethos that combined Nietzscheanism and Kantism in the form of self-overcoming and in the refusal to treat women as sexual objects or implements. In 1905, socialist feminist Rosa Mayreder published her Zur Kritik der Weiblichkeit (Toward a Critique of Femininity), a critical response to Weininger. The feminist movement at the time, in Germany as in the United States, was either socialistsyndicalist or it was a Schutz der Mutterreicht. Feminism as such, like the homosexual movement, was coming into its own, fraught with opposition, and opposed on all fronts from philosophy to pseudoscience.

Weininger never read Mayreder. He had committed suicide in 1903, shooting himself in the chest in the hotel where Beethoven died. His book was a hybrid of extensive cytology, evolutionism, and zoology, married to a philosophical framework that synthesized Nietzsche, Kant, and Schelling (particularly the latter's treatise on human freedom). The two parts did not go together, because, as George Canguilhem argued about the quest to define pathology relative 
to a unitary static standard of normalcy, Weininger defined the poles of the masculine and the feminine_-between which all of us are situated - in Idealistic terms. Predictably, or tragically, the masculine was aligned with activity, positivity, and given the valence of one: unity, singularity. The feminine was aligned with inactivity, but also Kuppelei, a curious German word hovering between copulation and coupling, the "-ei" being pejorative. The female was passive, but the female was eros, in a relational sense; that is, she came into her function of Kuppelei under the masculine gaze, without which she was essentially nothing. Upon his suicide, the book flew off the shelves. It influenced Wittgenstein, D. H. Lawrence, James Joyce, Heinrich Boll, and a host of others. Karl Kraus, the editor of Die Fackel (The Torch), defended it for years, against Freud and against other German intellectuals. Kraus is the satirist of whom Adorno said that we are wrong not to study his monumental oeuvre, and Die Fackel was printed from the late 1890s until Hitler's election in 1933. Kraus defended Weininger because he believed the fundamental thesis of the multiple sexuation of the body. He defended him against the more traditionalist, Biedermeyer theses on sexuality in Freudianism.

In 1906, Paul Julius Möbius published a work in neuropsychiatry titled Über den physiologischen Schwachsinn des Weibes (The Physiological Feeble-Mindedness of the Female). In France, from 1880 to the turn of the century, the extraordinary Jean-Martin Charcot was carrying on his practice in neurology at the Salpêtrière, effecting a triage between epileptics and epileptoid hysteria, looking ongoingly for a physiological seat in the brain for hysteria, but arguing all the while that hysteria was the result of physiological degeneration and a mysterious “chose sexuelle." Of course, Charcot was Freud's teacher, along with Wilhelm Fliess, the Berlin ear, nose and throat doctor who worked out a calculation of periodicity in man as a parallel to feminine hormonal cycles. 
This is a long and terrible time over which something like a wave of forgetfulness has washed. No doubt because it came to a screeching halt, for better or for worse, with the rise of Fascism in France, Italy, Germany, and Austria, a political movement that drew significant energy from persons nostalgic for an age of clarity in which hierarchy and binaries were left undisturbed. Very good work has been done in the past 30 years on the logic of the fin-de-siècle. What I am emphasizing here is firstly how, as the very question of sex, reproduction, and sexuation was being brought to light, it was from the outset tied to anti-Semitism, colonialist racism, and theories of hereditary degeneration as leading to delinquency and criminality. It is the signal contribution of Alexis Shotwell's book that she interrogates the question of sex and sexuation in many of its intersections, from gender to race to inter-gender. We can see, from the "neuroscience" of the time—-much more clearly than we can see today—how cultural values and implicit knowledge shaped and oriented research like that of Nordau, Möbius, and Lombroso. But the researchers were so much more numerous. And in a sense, Freud quite deliberately held himself apart, because he recognized in theories of degeneration, Entartung, for Judenhass. Kraus held himself apart, on the basis of his opposition to all psychiatric attempts to determine, diagnose, or treat "sexual dysfunction." I am arguing, in unmitigated homage to Alexis Shotwell's Knowing Otherwise, that the intersection of discourses of race, class, ethnicity, and gender represents one of the most dangerous points of intervention into philosophical and scientific discourse. She has taken up that challenge and, given the courage and uncompromising quality of her arguments, I can only hope that her work will find an echo in philosophy and in scientific discourses less naïve than that of Deborah Rudacille's The Riddle of Gender.

I had originally written an appreciative study that stayed closer to the book, in which I recalled Shotwell's four domains of implicit understanding: “foundationally non-propositional 
knowledge, embodied understanding, potentially propositional knowledge currently held as tacit or distal, and affective or emotional knowledge" (Shotwell 48). I praised her extraordinary synthesis of Hubert Dreyfus, Michael Polanyi, Hans Georg Gadamer, Richard Shusterman and Pierre Bourdieu, and I examined the way in which art and literature allowed us to extend Susan Babbitt's "dreaming different futures and worlds." I suggested that Shotwell's exploration of the implicit understanding sustaining and structuring racist forms of common sense, and feeding what she calls (following Himani Bannerji) "epistemologies of ignorance" (31), would be well served by Husserl's and Merleau-Ponty's investigations into embodied passive syntheses, memory, and the multiform phenomena of association and intersubjectivity. But rather than going in that direction, I chose to review how it is that work being done today is indebted to, yet very different from, the anguished investigations of the turn of the century into sexuality and civilizational decline. The two periods cannot and should not be amalgamated, and we must hope, faintly, that the openness, contestation, and destabilization in art, literature, and philosophy does not lead to a call for a political crackdown comparable to that of the 1930s. But we must draw courage also, I think, to pursue these questions knowing that anti-racism, anti-queer phobia, and feminism were born together, if not always seeing eye to eye, and that for a brief moment, debates in Europe ventured into metaphoric uncharted waters, before being silenced by nostalgia, fear, and shame misunderstood.

\section{Notes}

${ }^{1}$ The text Sappho und Sokrates: Wie erklärt sich die Liebe der Männer und Frauen zu Personen des eigenen Geschlechts (Sappho and Socrates: How is the Love of Men and Women toward Persons of the Same Sex to be Explained)? was originally published under the name of Theodor Ramien. 


\section{Works Cited}

Note: The number of works mentioned as part of this historical survey is too great to be cited in a review essay. I will therefore cite only the ones that played a role in the arguments I developed.

Babbitt, Susan. Impossible Dreams, Rationality, Integrity, and Moral Imagination. Boulder: Westview Press, 1996.

Bannerji, Himani. Thinking Through: Essays on feminism, Marxism and Anti-racism. Toronto: Women's Press, 1995.

Bergo, Bettina. "Otto Weininger and the (Political) Problem of Categories." The Movement of Nothingness: Trust in the Emptiness of Time. Ed. Daniel M. Price and Ryan J. Johnson. Aurora: The Davies Group, 2013. 51-72.

Charcot, Jean-Martin. Leçons du mardi à la Salpêtrière, I: Policliniques 1887-1888. Paris: Claude Tchou, 2002.

—. Leçons du mardi à la Salpêtrière, II : Policliniques 1888-1889. Paris: Claude Tchou, 2002.

Hirschfeld, Magnus. Sappho und Sokrates: Wie erklärt sich die Liebe der Männer und Frauen zu Personen des eigenen Geschlechts? Leibzig: Max Spohr, 1896.

-. Geschlechtskunde, Vol. I: Die körperseelischen Grundlagen. Stuttgart: Julius Püttmann Verlagsbuchhandlung., 1926.

Husserl, Edmund. Analyses Concerning Passive and Active Syntheses: Lectures on Transcendental Logic. Trans. Anthony Steinbock. Dordrecht: Kluwer Academic Publishers, 2001.

Kraus, Karl. Was wir Umbringen: "Die Fackel” von Karl Kraus. Ed. Heinz Lunzer, V. LunzerTalos, Marcus G. Patka. Vienna: Mandelbaum, 1999.

—. Das Karl Kraus Lesebuch. Ed. Hans Wollschläger. Zürich: Diogenes, 1980.

LeRider, Jacques. Modernity and Crises of Identity: Culture and Society in Fin-de-Siècle Vienna. Trans. Rosemary Morris. New York: Continuum Books, 1993.

- Le cas Otto Weininger: Racines de l'antiféminisme et de l'antisémitisme. Paris: Presses Universitaires de France, 1982.

Lombroso, Cesare. 1895. The Man of Genius. London: Charles Scribner's Sons, 1895. 
Luft, David S. Eros and Inwardness in Vienna: Weininger, Musil, Doderer. Chicago: University of Chicago Press, 2003.

Mayreder, Rosa. Zur Kritik der Weiblichkeit. Vienna: Mandelbaum, 1998.

- A Survey of the Woman Problem. Trans. Hermann Scheffauer. Westport: Hyperion Press, 1982.

Merleau-Ponty. Maurice. Institution and Passivity: Course Notes from the Collège de France (1954-1955). Ed. Dominique Darmaillacq, Claude Lefort, and Stéphanie Ménasé. Trans. Leonard Lawlor and Heath Massey. Evanston: Northwestern University Press, 2010.

Möbius, Paul Julius. Über den physiologischen Schwachsinn des Weibes. Munich: Matthes und Seitz, 1977.

Nordau, Max. Degeneration. Lincoln: University of Nebraska Press, 1993.

Rudacille, Deborah. The Riddle of Gender: Science, Activism, and Transgender Rights. New York: Pantheon Books, 2005.

Schiller, Francis. A Möbius Strip: Fin de Siècle Neuropsychiatry and Paul Möbius. Berkeley: University of California Press, 1982.

Sengoopta, Chandak. Otto Weininger: Sex, Science, and Self in Imperial Vienna. Chicago: University of Chicago Press, 2000.

Shotwell, Alexis. Knowing Otherwise: Race, Gender, and Implicit Understanding. University Park: Pennsylvania State University Press, 2011.

Weininger, Otto. Sex and Character: An Investigation of Fundamental Principles. Eds. D. Steuer and L. Marcus. Trans. Ladislaus Löb. Bloomington: Indiana University Press, 2006.

-. Geschlecht und Charakter: Eine principielle Untersuchung. Vienna and Leipzig: Wilhelm Braumüller, 1921. 